\title{
Organic extracts from Indigofera suffruticosa leaves have antimicrobial and synergic actions with erythromycin against Staphylococcus aureus
}

\author{
Ana Thereza Bezerra dos Santos ${ }^{1}$, Tiago Ferreira da Silva Araújo ${ }^{1}$, \\ Luis Cláudio Nascimento da Silva ${ }^{2 *}$, Cleideana Bezerra da Silva ${ }^{1}$, \\ Antonio Fernando Morais de Oliveira ${ }^{3}$, Janete Magali Araújo ${ }^{4}$, Maria Tereza dos Santos Correia $^{2}$ and \\ Vera Lúcia de Menezes Lima ${ }^{1 *}$ \\ Laboratório de Química e Metabolismo de Lipídios e Lipoproteínas, Departamento de Bioquímica, Centro de Ciências Biológicas, Universidade Federal de \\ Pernambuco, Recife, Brazil \\ ${ }^{2}$ Laboratório de Glicoproteínas, Departamento de Bioquímica, Centro de Ciências Biológicas, Universidade Federal de Pernambuco, Recife, Brazil \\ ${ }^{3}$ Laboratório de Ecologia Aplicada e Fitoquímica, Departamento de Botânica, Centro de Ciências Biológicas, Universidade Federal de Pernambuco, Recife, Brazil \\ ${ }^{4}$ Laboratório de Genética de Microrganismos, Departamento de Antibióticos, Centro de Ciências Biológicas, Universidade Federal de Pernambuco, Recife, Brazil
}

\section{Edited by:}

Jem Stach, University of

Newcastle, UK

\section{Reviewed by:}

Guilherme Lanzi Sassaki,

Universidade Federal do Paraná,

Brazil

Atte Von Wright, University of

Eastern Finland, Finland

Marcela Carina Audisio, Instituto de

Investigaciones Para la Industria

Química (INIQUI)-CONICET,

Argentina

Ilkin Yucel Sengun, Ege University,

Turkey

\section{*Correspondence:}

Luis Cláudio Nascimento da Silva and Vera Lúcia de Menezes Lima, Departamento de Bioquímica, Centro de Ciências Biológicas, Universidade Federal de Pernambuco, Avenida Professor

Moraes Rêgo, S/N, Cidade

Universitária, CEP 50670-420,

Recife, Brazil

e-mail: luisclaudionsilva@

yahoo.com.br;

lima.vera.ufpe@gmail.com
A characteristic feature of Staphylococcus aureus is its ability to acquire resistance to antimicrobial agents. There is a need, therefore, for new approaches to combat this pathogen; for example, employing a combination of plant-derived products and antibiotics to overcome bacterial resistance. Indigofera suffruticosa is a plant popularly used to treat infections and has verified antimicrobial action. Here, we investigate the antimicrobial activity of different extracts from I. suffruticosa against $S$. aureus and their synergistic effects with erythromycin. Leaves of $I$. suffruticosa were extracted sequentially using diethyl ether, chloroform and acetone and the antimicrobial activity of each extract then tested against nine clinical isolates of $S$. aureus. Minimal inhibitory concentration (MIC) and minimal bactericidal concentration $(\mathrm{MBC})$ were determined by microdilution tests, while the fractional inhibitory concentration (FIC) was assessed by checkerboard assay. All organic solvent extracts showed antimicrobial activity against $S$. aureus strains. The acetone extract was the most potent inhibitor of $S$. aureus (MIC and MBC of 0.78 and $3.12 \mathrm{mg} / \mathrm{mL}$ ), followed by the chloroform extract (MIC and MBC of 3.12 and $6.25 \mathrm{mg} / \mathrm{mL}$ ). Furthermore, acetone or chloroform extracts of $I$. suffruticosa enhanced the activity of erythromycin against $S$. aureus $(F I C \leq 0.5)$. We conclude that organic extracts from leaves of I. suffruticosa, alone or combined with erythromycin, are promising natural products for the development of new anti-S. aureus formulations.

Keywords: plant extracts, antibacterial agents, macrolide antibiotic, $S$. aureus

\section{INTRODUCTION}

Patients in hospital intensive care units are at risk of acquiring nosocomial infections due to the use of invasive devices and/ or extended hospital stay (Streit et al., 2004). Long-term hospitalization may further complicate patient health by exposure to various antimicrobial agents. Additionally, the indiscriminate use of antibiotics in treating infections promotes bacterial evolution and emergence of resistance strains (Palmer and Kishony, 2013; Tavares et al., 2013). Staphylococcus aureus is an important pathogen associated with nosocomial human infections, and this microorganism has successfully evolved numerous strategies to resist different antibiotics (Coutinho et al., 2009; Chung et al., 2011). Such increases in antibiotic resistant $S$. aureus strains drives research discovery of new antimicrobial agents and the development of alternative therapeutic strategies. These include plant extracts, which have considerable antimicrobial potential (Leite et al., 2006; da Silva et al., 2013; Zakavi et al., 2013).

Medicinal plants are important health and economic components used by many cultures for thousands of years (Agra et al., 2008; Silva et al., 2012). According to the World Health Organization approximately $80 \%$ of the global population uses medicinal plants or herbal medicine for primary health care (Pereira et al., 2012). Brazil has the highest plant diversity of any country and represents $20 \%$ of biodiversity in the world. Indigofera suffruticosa Mill (Fabaceae, Papilionidae) is a plant originally from Antilles and Central America, popularly known as "anileira" or "anil," and was introduced into Brazil for the extraction of indigo, a blue dye blue (Indigo Blue) widely used by the textile industry. Although some toxic effects are reported for this plant, such as hemolytic anemia and hemoglobinuria in 
Table 1 | Pharmacological potential of Indigofera suffruticosa.

\begin{tabular}{ll}
\hline Scientific account & Related compounds \\
\hline $\begin{array}{ll}\text { Gastroprotective agent acute ulcer stimulating prostaglandin, mucus and } \\
\text { HSP70. (Luiz-Ferreira et al., 2011) }\end{array}$ & $\begin{array}{l}\text { Ethyl acetate fraction from methanolic extract showed the best action and } \\
\text { the authors highlighted the role of role of flavonoids and alkaloids presents } \\
\text { in AcF as active compounds }\end{array}$ \\
\hline In vivo action against Pediculosis capitis (García Calixto et al., 2011) & $\begin{array}{l}\text { An effective treatment using 5\% I. suffruticosa Mill tincture was reported } \\
\text { in a patient infested with Pediculosis capitis }\end{array}$ \\
\hline Immunostimulatory and antitumoral actvities in vitro (Lopes et al., 2011) & $\begin{array}{l}\text { This study evaluated the action of both alkaloid fraction and pure indigo. } \\
\text { Indigo showed high activity which suggest that it is the major active } \\
\text { principle in I. suffruticosa }\end{array}$
\end{tabular}

Antimycobacterial (Carli et al., 2010)

These authors did not isolate or detected any compounds. The methanolic extract showed better activity than dichloromethane

Anticonvulsant effect (Almeida et al., 2013)

Alkaloids, flavonoids, steroids, proteins, carbohydrates, indigo carmine and essential oils (Linalool and Pinene) were detected in the methanolic extract

Anti-inflammatory property in vivo (Chen et al., 2013a)

Eight phenolic compounds were quantified: salicylic acid, syringic acid (major compounds) $\rho$-coumaric acid, vanillin, syringaldehyde, quercetin, isoliquiritigenin, formononetin. Salicylic acid was found in the plasma of mice fed with I. suffruticosa extracts

In vivo increase of Phase II detoxification enzyme and glutathione levels (Chen et al., 2013b)
The authors reported the same compounds quantified by Chen et al. (2013a). Ethanolic extracts showed the best action on the induction of phase II detoxification enzyme, and syringic acid was the most active among phenolic compounds detected, however, it was less potent than ethanolic extracts cattle and guinea pig (Salvador et al., 2011), it has been used in traditional medicine both externally and internally (Barros and Teixeira, 2008). Moreover, pharmacological effects of I. suffruticosa have been confirmed scientifically, such as anti-inflammatory (Chen et al., 2013a), anticonvulant (Almeida et al., 2013) and wound healing (Luiz-Ferreira et al., 2011) (Table 1). Previous work by our group has shown that aqueous infusions of I. suffruticosa leaves have inhibitory activity against $S$. aureus and dermatophyte strains (fungi) (Leite et al., 2006), though their action against clinical isolates and synergic potential have yet to be studied.

Synergistic assessments have become a key tool in phytomedicine research in recent years, and uses of antibiotics in combination with herbal products have been investigated as antimicrobials for $S$. aureus resistant strains (Wagner and Ulrich-Merzenich, 2009). Some studies have used erythromycin, a 14-membered ring macrolide antibiotic and therefore part of the Macrolide-Lincosamide-Streptogramin-B (MLSB) family, as a representative drug to evaluate combinatory effects of plantderived products (Chan et al., 2013, 2015). Antibiotics from the MLSB family serve as an important combatant against $S$. aureus methicillin resistant (MRSA) strains, which are a major cause of disease in the general population and hospital-acquired infections (Pantosti, 2012). MLSB comprises three unrelated groups (macrolide, lincosamide and streptogramin-B) that share the same binding site in bacterial ribosome. It is possible, therefore, that a synergistic effect for one group might predict a similar action from the other groups.
Given this background, our study aimed to define the antimicrobial activities of different organic extracts from I. suffruticosa leaves against $S$. aureus strains (MRSA and MSSA), and then to examine synergistic actions with erythromycin.

\section{MATERIALS AND METHODS CHEMICALS}

Dimethylsulfoxide (DMSO), erythromycin and 7-hydroxy3H-phenoxazin-3-one-10-oxide sodium salt (Resazurin) was purchased from Sigma-Aldrich Chemical Company, St. Louis, MO, while Mueller-Hinton Agar and Nutrient Agar medium were from HIMEDIA Laboratories ${ }^{\circledR}$. Diethylether, chloroform and acetone were obtained from Merck, Darmstadt, Germany.

\section{PLANT MATERIAL AND PREPARATION OF ORGANIC EXTRACTS}

Leaves of $I$. suffruticosa were collected in São Caetano, Pernambuco, Brazil (latitude: $08^{\circ} 19^{\prime} 33^{\prime \prime}$ S; longitude: $36^{\circ} 04^{\prime}$ $\left.21^{\prime \prime} \mathrm{W}\right)$ between 10 and 11 a.m. The plant was identified by Dr. Marlene Carvalho Alencar Barbosa (Department of Botany, UFPE) and a voucher specimen deposited at the UFP Geraldo Mariz Herbarium-UFPE (identification number 45.217).

Organic extracts were prepared by successively extracting dried leaves of I. suffruticosa ( $100 \mathrm{~g}$ ) with $200 \mathrm{~mL}$ of diethyl ether, chloroform or acetone, common solvents arranged in order of increasing polarity. Briefly, the leaf powder was homogenized firstly with $200 \mathrm{~mL}$ of diethyl ether for $2 \mathrm{~h}$ in a mechanical stirrer, kept refrigerated overnight $\left(4^{\circ} \mathrm{C}\right)$ and filtered with Whatman 
no. 1 paper. The solvent was then removed under reduced pressure in a rotary evaporator at $45^{\circ} \mathrm{C}$ to produce diethyl ether extract. The plant material which was not extracted by diethyl ether was then homogenized with $200 \mathrm{~mL}$ chloroform and all extraction process was repeated generating the chloroform extract. Finally, the remaining powder was submitted to acetone extraction to produce acetone extract. All dried organic extracts of $I$. suffruticosa were stored at $-20^{\circ} \mathrm{C}$ until use and dissolved in dimethyl sulfoxide (DMSO, 1\%) before each test.

\section{PHYTOCHEMICAL SCREENING}

An approximate amount of diethyl ether, chloroform and acetone extracts from I. suffruticosa leaves were subjected to phytochemical analysis to ascertain the presence of secondary metabolites such as alkaloids, flavonoids, phenylpropanoids, triterpenoids and volatile oil in according to Wagner and Bladt (2009). Briefly, compounds classes were visualized as aid thin layer chromatography (TLC) on silicagel 60 F254 (Merck), mobile phase standard and Dragendorff, NEU-PEG, $\mathrm{KOH}-E$ thanol, Liebermann-Burchard and vanillin-sulfuric acid reagents, respectively. Tests for tannins, saponins and other heterosides were not performed due to the low polarity of the extracts.

\section{ANTIMICROBIAL ASSAYS}

\section{Staphylococcus aureus strains}

The antimicrobial activity was tested against the following microorganisms provided by the Departamento de Antibióticos, Universidade Federal de Pernambuco (UFPEDA): Staphylococcus aureus (UFPEDA 02), and some isolated strains of S. aureus originally obtained from: vaginal secretion (UFPEDA 660); catheter tip (UFPEDA 663); urine sample (UFPEDA 670); blood sample (UFPEDA 672); prostate secretion (UFPEDA 676); wound secretion (UFPEDA 677 and 679); ocular secretion (UFPEDA 687). Strains UFPEDA 670 and 672 are classified as MRSA strains (Table 2). All strains were and maintained in Mueller-Hinton Agar (MHA) and stored at $4^{\circ} \mathrm{C}$.

Table 2 | Susceptibility to antibiotics of Staphylococcus aureus strains $^{a}$.

\begin{tabular}{|c|c|c|c|c|c|}
\hline \multirow[t]{2}{*}{ UFPEDA } & \multirow[t]{2}{*}{ Source } & \multicolumn{4}{|c|}{ Susceptibility to antibiotics } \\
\hline & & Oxacillin & Cefoxitin & Erythromycin & Clindamycin \\
\hline 02 & ATCC 6538 & S & S & S & S \\
\hline 660 & Vaginal secretion & S & S & S & S \\
\hline 663 & Catheter tip & S & S & S & S \\
\hline $670^{b}$ & Urine sample & $\mathrm{R}$ & $\mathrm{R}$ & $\mathrm{R}$ & $\mathrm{R}$ \\
\hline $672^{b}$ & Blood sample & $\mathrm{R}$ & $\mathrm{R}$ & $\mathrm{R}$ & $\mathrm{R}$ \\
\hline 676 & Prostate secretion & S & S & S & S \\
\hline 677 & Wound secretion & S & $\mathrm{R}$ & $\mathrm{R}$ & S \\
\hline 679 & Wound secretion & $\mathrm{S}$ & S & $\mathrm{R}$ & S \\
\hline 687 & Ocular secretion & $S$ & $S$ & $S$ & $S$ \\
\hline
\end{tabular}

$R$, resistant; $S$, sensitive. ${ }^{a}$ Data provided by UFPEDA Collection. ${ }^{b} M R S A$.

\section{Determination of antibacterial activity using the disc diffusion method}

The antibacterial activity of the organic extracts of I. suffruticosa leaves was determined by the disc diffusion method (de Oliveira et al., 2012). Briefly, all clinically isolated S. aureus strains were grown on MHA medium at $37^{\circ} \mathrm{C}$ for $18 \mathrm{~h}$, suspended in distilled water (approximately $1.5 \times 10^{8} \mathrm{CFU} / \mathrm{mL}$ ) and $100 \mu \mathrm{L}$ aliquots of bacterial suspension were immediately inoculated in Petri dishes containing MHA medium. Sterile paper discs (6 mm diameter) containing $20 \mu \mathrm{L}$ organic extracts of I. suffruticosa $(100 \mathrm{mg} / \mathrm{mL})$ were applied to the agar and the Petri dishes incubated at $37^{\circ} \mathrm{C}$ for an additional $18 \mathrm{~h}$. Following incubation, the diameter of the inhibition zone (DIZ) of growth was measured, using DMSO as negative control.

\section{Effects of temperature and $\mathrm{pH}$ on antimicrobial activity}

The antimicrobial activity of each $I$. suffruticosa extract against S. aureus UFPEDA 02 was determined. Samples were placed in sterile tubes and kept for $30 \mathrm{~min}$ at different temperatures (28, 30,60 , and $100^{\circ} \mathrm{C}$ ), or were stored at a different $\mathrm{pH}$ for $30 \mathrm{~min}$ at $25^{\circ} \mathrm{C}$, using $1 \mathrm{M} \mathrm{NaOH}$ or $1 \mathrm{M} \mathrm{HCl}$ to adjust the $\mathrm{pH}$ range between 3 and 10 . The antibacterial activity of treated extracts was tested using the disc diffusion method, as described above.

\section{Determination of minimum inhibitory concentration (MIC) and minimum bactericidal concentration (MBC)}

The minimal inhibitory concentration (MIC) was determined by a microdilution broth susceptibility assay (Clinical and Laboratory Standards Institute, 2011). Two-fold serial dilutions of the organic extracts of I. suffruticosa containing $50-0.20 \mathrm{mg} / \mathrm{mL}$ in DMSO were prepared in Mueller-Hinton Broth (MHB; $200 \mu \mathrm{L}$ ) in a 96-well microtiter plate. Bacterial suspensions were prepared from each $S$. aureus strains freshly grown in MuellerHinton broth (Merck) (approximately $1.5 \times 10^{8} \mathrm{CFU} / \mathrm{mL}$,) and $10 \mu \mathrm{L}$ of this suspension was added to each well. After incubation at $37^{\circ} \mathrm{C}$ for $24 \mathrm{~h}$, bacterial growth was recorded using a Resazurin solution $(0.01 \%)$. MIC was the lowest concentration at which no color change (from purple to pink) was observed. Afterwards, cultures were seeded in MHA medium and incubated for $24 \mathrm{~h}$ at $37^{\circ} \mathrm{C}$ to determine the minimum bactericidal concentration (MBC), which corresponds to the lowest amount of extract that kills $S$. aureus. All experiments were performed in triplicate.

\section{Evaluation of combinatory effects of extracts and erythromycin}

Combinatory effects between organic extracts of I. suffruticosa and erythromycin were assessed using the checkerboard test against the strain UFPEDA 02. Briefly, samples with different proportions of plant extract:drug (final volume: $20 \mu \mathrm{L}$ ) were prepared from stock solutions of each extract $(50 \mathrm{mg} / \mathrm{mL})$ and erythromycin $(1 \mathrm{mg} / \mathrm{mL})$ and antibacterial activity was tested as described for MIC determination (da Silva et al., 2013). The Fractional Inhibitory Concentration ( $\Sigma$ FIC) was calculated according to the equation:

$$
\Sigma \mathrm{FIC}=(\mathrm{MICE}+\mathrm{D} / \mathrm{MICE})+(\mathrm{MICD}+\mathrm{E} / \mathrm{MICD})
$$


MICE+D: minimal inhibitory concentration of extract in combination with erythromycin; MICD+E: minimal inhibitory concentration of erythromycin in combination with extract. Results were considered: synergistic $(\Sigma \mathrm{FIC}<0.5)$; additive $(0.5<$ $\Sigma$ FIC $<1)$; non-interactive $(1<\Sigma$ FIC $<4)$; or antagonist $(\Sigma$ FIC > 4) (Vuuren and Viljoen, 2011).

\section{STATISTICAL ANALYSIS}

Each experiment was performed in triplicate and results are expressed as the mean \pm standard deviation (SD). Statistical analyses were performed by ANOVA and unpaired Student's $t$-test. All analyses were carried out using software StatView, version 4.5, Abacus Concept, Inc, Berkeley, CA. Differences were considered significant at $p<0.05$. The correlation indices were calculated using the Pearson coefficient $(\rho)$.

\section{RESULTS}

\section{PHYTOCHEMICAL ANALYSIS}

TLC analysis revealed the presence of flavonoids, phenylpropanoids, triterpenoids and volatile oils in all three extracts.

Table 3 | Phytochemical analysis of organic extract from leaves of Indigofera suffruticosa.

\begin{tabular}{lccc}
\hline Compounds class & \multicolumn{3}{c}{ Indigofera suffruticosa extracts } \\
\cline { 2 - 4 } & Ether & Chloroform & Acetone \\
\hline Alkaloids & - & + & - \\
Flavonoids & + & + & ++ \\
Phenylpropanoids & ++ & + & + \\
Triterpenoids & + & + & + \\
Volatile oils & + & ++ & + \\
\hline
\end{tabular}

(-) absent, (+) weak, (++) strong.

Table 4 | Antimicrobial activity of organic extracts from leaves of Indigofera suffruticosa against Staphylococcus aureus strains.

\begin{tabular}{|c|c|c|c|}
\hline \multirow[t]{2}{*}{ S. aureus strains } & \multicolumn{3}{|c|}{$\begin{array}{l}\text { Organic extracts of leaves of } \\
\text { Indigofera suffruticosa DIZ }\end{array}$} \\
\hline & Ether & Chloroform & Acetone \\
\hline 02 & $34.7 \pm 0.6^{a, 1}$ & $36.0 \pm 0.0^{\mathrm{a}, 1}$ & $35.7 \pm 1.1^{\mathrm{a}, 1}$ \\
\hline 660 & $29.0 \pm 1.7^{\mathrm{b}, 1}$ & $28.0 \pm 2.0^{b, 1}$ & $28.0 \pm 2.0^{b, 1}$ \\
\hline 663 & $28.7 \pm 0.6^{\mathrm{b}, 1}$ & $27.7 \pm 0.6^{b, 1}$ & $26.7 \pm 0.6^{b, 1}$ \\
\hline 670 & $32.7 \pm 1.1^{\mathrm{a}, 1}$ & $27.7 \pm 2.5^{b, 2}$ & $30.7 \pm 0.6^{b, 2}$ \\
\hline 672 & $32.6 \pm 1.1^{\mathrm{a}, 1}$ & $32.3 \pm 0.6^{c, 1}$ & $31.0 \pm 3.0^{b, 1}$ \\
\hline 676 & $27.3 \pm 0.6^{\mathrm{b}, 1}$ & $25.3 \pm 0.6^{b, 1}$ & $26.3 \pm 0.6^{b, 1}$ \\
\hline 677 & $30.0 \pm 1.0^{\mathrm{b}, 1}$ & $29.0 \pm 1.7^{b, 1}$ & $29.7 \pm 0.6^{b, 1}$ \\
\hline 679 & $29.0 \pm 1.0^{b, 1}$ & $26.3 \pm 2.3^{b, 1}$ & $25.7 \pm 2.1^{b, 1}$ \\
\hline 687 & $26.7 \pm 2.3^{b, 1}$ & $26.0 \pm 2.6^{b, 1}$ & $25.3 \pm 2.1^{b, 1}$ \\
\hline Average DIZ & $30.08 \pm 2.7$ & $28.7 \pm 3.4$ & $28.78 \pm 3.4$ \\
\hline
\end{tabular}

DIZ values are expressed in $\mathrm{mm}$.

${ }^{*}$ Same superscript letter $(a, b, c)$ indicates no significant difference $(p>0.05)$ between DIZ values from different strains for each solvent (same column).

** Same superscript number $\left({ }^{1,2}\right)$ indicates no significant difference $(p>0.05)$ between DIZ values from different solvents against each strain (same row).
In most of the tests performed, only quantitative differences were found. Thus, flavonoids, phenylpropanoids and volatile oils predominated in acetone, ether and chloroform extracts, respectively. Alkaloids or nitrogen-containing compounds were detected only in the chloroform extract of I. suffruticosa (Table 3 ).

\section{ANTIBACTERIAL ACTIVITY OF ORGANIC EXTRACTS FROM LEAVES OF I. SUFFRUTICOSA}

All organic extracts of leaves of $I$. suffruticosa showed antimicrobial activity against different $S$. aureus strains. However, the inhibition varied according to the extract and test strain with DIZ values ranging from $25.3 \pm 2.1$ to $36.0 \pm 1.0 \mathrm{~mm}$ (Table 4). All extracts were active against both MRSA strains (UFPEDA 670 and UFPEDA 672) with DIZ values $>30.0 \mathrm{~mm}$, except for the chloroform extract which gave a DIZ of $27.7 \pm 2.5 \mathrm{~mm}$ for strain UFPEDA 670. Diethyl ether extracts showed the best inhibition $(30.08 \pm 2.69 \mathrm{~mm})$, followed by acetone $(28.79 \pm 3.35 \mathrm{~mm})$ and chloroform $(28.7 \pm 3.42 \mathrm{~mm})$, however no significant differences were observed between these average DIZ values $(p>$ $0.05)$. Furthermore, strong correlations were found between the DIZ of all extracts with $\rho$-values of $0.86,0.94$, and 0.92 for ethyl/chloroform, and chloroform/acetone ethyl/acetone extracts, respectively. The antimicrobial activity of the extracts was not affected $(p>0.05)$ after high temperature treatment (Figure 1A) or variation of $\mathrm{pH}$ (Figure 1B), except for the ether extract which was notably more active at $\mathrm{pH} 8(p>0.05)$.

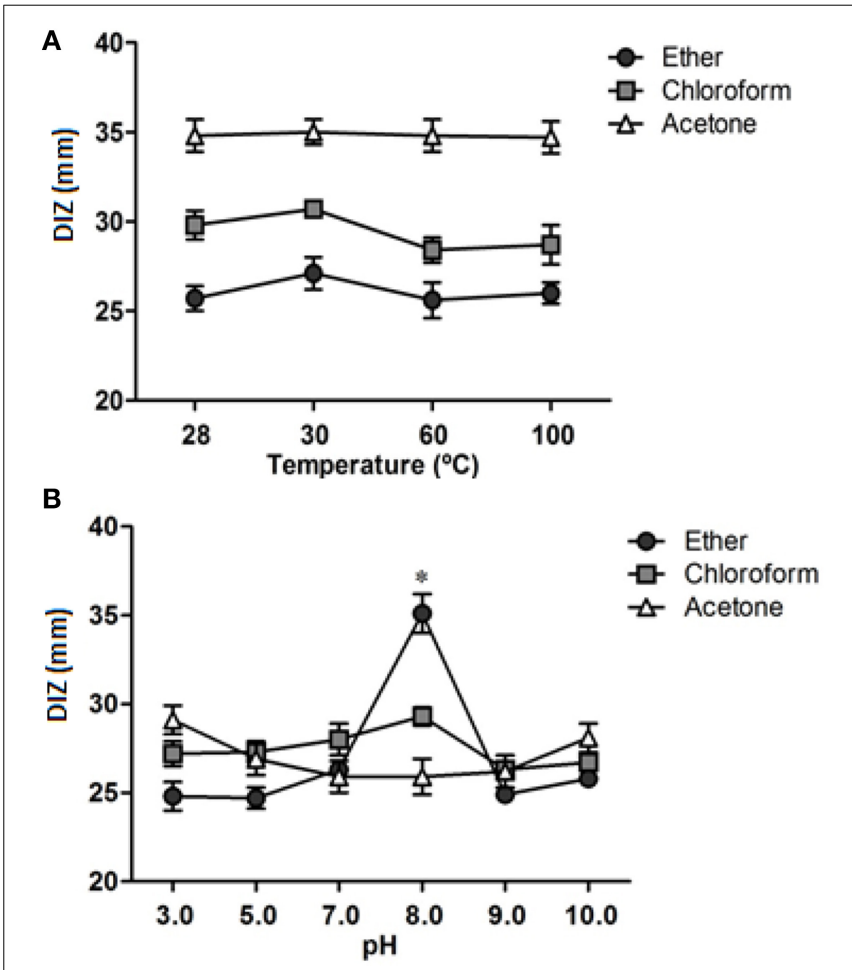

FIGURE 1 | Stability of organic extracts of leaves of Indigofera suffruticosa. (A) Effect of temperature on the stability of organic extracts of $I$. suffruticosa. (B) Effect of $\mathrm{pH}$ on the stability of organic extracts of $I$. suffruticosa. DIZ-inhibition zone diameter. *Significant differences in relation to control. 
Table 5 | Minimum inhibitory concentration and minimum bactericidal concentration of organic extracts from leaves of Indigofera suffruticosa against Staphylococcus aureus strains.

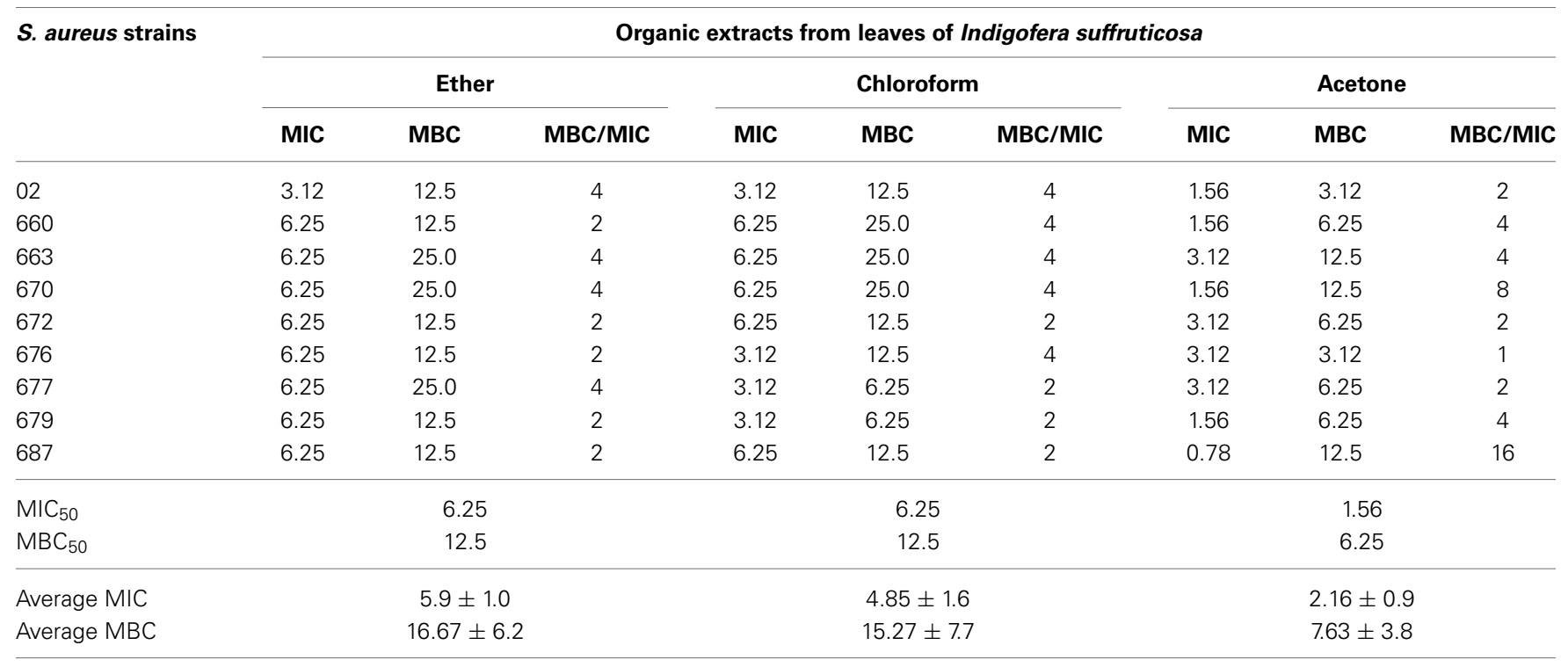

MIC, minimal inhibitory concentration; $M B C$, minimal bactericidal concentration.

$M I C_{50}$, concentration able to inhibit $50 \%$ of strains; $M B C_{50}$, concentration able to kill $50 \%$ of strains.

MIC, MIC $50, M B C$ and $M B C_{50}$ are expressed in $\mathrm{mg} / \mathrm{mL}$.

The MIC and MBC values ranged from 0.78 to $6.25 \mathrm{mg} / \mathrm{mL}$ and 3.12 to $25.0 \mathrm{mg} / \mathrm{mL}$, respectively, with the acetone extract having the lowest values (Table 5). The $\mathrm{MIC}_{50}$ (minimum concentration able to inhibit $50 \%$ of strains) was $1.56 \mathrm{mg} / \mathrm{mL}$ for the acetone extract, and $6.25 \mathrm{mg} / \mathrm{ml}$ for both ether and chloroform extracts. Similarly, the $\mathrm{MBC}_{50}$ (minimum concentration able to kill $50 \%$ of strains), for the acetone extract was $6.25 \mathrm{mg} / \mathrm{mL}$, but $12.5 \mathrm{mg} / \mathrm{mL}$ for ether and chloroform extracts. Additionally, the average MIC and MBC of acetone extract $(2.16 \pm 0.9$ and $7.63 \pm 3.8$, respectively) were lower $(p>0.05)$ than other extracts $(4.85 \pm 1.6$ and $15.27 \pm 7.7$ for ether extract; and $5.9 \pm 1.0 \mathrm{mg} / \mathrm{mL}$ and $16.67 \pm 6.2 \mathrm{mg} / \mathrm{mL}$ for chloroform). The three extracts also differed in their MBC/MIC ratio (Pankey and Sabath, 2004); although ether and chloroform extracts showed exclusively bactericidal effects (MBC/MIC ratios ranged from 2 to 4), the acetone extract had both bactericidal and bacteriostatic actions, however this extract was a bactericidal agent for almost all S. aureus strains tested (77.78\%).

\section{COMBINATORY EFFECTS OF ORGANIC EXTRACTS OF I. SUFFRUTICOSA AND ERYTHROMYCIN}

When the antimicrobial actions of erythromycin and I. suffruticosa organic extracts were tested in combination, additive, synergistic and non-interactive actions were observed (Table 6); importantly, no antagonistic effects were noted. Acetone extract and erythromycin showed synergistic effects (in five ratios (55.56\%; $\Sigma$ FIC values ranged from 0.3 to 0.5 ), additive effects $(0.6 \leq \Sigma$ FIC $\leq 0.8)$ in three and a non-interactive effect in only one (ratio of 1:9, drug:extract; $\Sigma$ FIC $=1.7$ ). For the chloroform extract and erythromycin combinations both synergistic $(0.2 \leq \Sigma$ FIC $\leq 0.4)$ and additive $(0.7 \leq \Sigma$ FIC $\leq 0.9)$ effects were equally found in four ratios and only one ratio gave a
Table 6 | Combinatory effects of organic extracts from leaves of Indigofera suffruticosa and erythromycin against $S$. aureus UFPEDA 02.

\begin{tabular}{|c|c|c|c|}
\hline \multirow[t]{2}{*}{$\begin{array}{l}\text { Erythromycin/ } \\
\text { Extracts proportion }\end{array}$} & \multicolumn{3}{|c|}{$\begin{array}{l}\text { Organic extracts from Indigofera } \\
\text { suffruticosa leaves ( } \Sigma \text { FIC) }\end{array}$} \\
\hline & Ether & Chloroform & Acetone \\
\hline $9: 1$ & 0.9 & 0.9 & 0.4 \\
\hline $8: 2$ & 0.9 & 0.4 & 0.4 \\
\hline $7: 3$ & 0.7 & 0.7 & 0.3 \\
\hline $6: 4$ & 0.6 & 0.3 & 0.6 \\
\hline $5: 5$ & 0.6 & 0.2 & 0.5 \\
\hline $4: 6$ & 0.8 & 0.8 & 0.8 \\
\hline $3: 7$ & 1.2 & 0.3 & 0.3 \\
\hline $2: 8$ & 0.8 & 0.8 & 0.8 \\
\hline $1: 9$ & 0.8 & 1.7 & 1.7 \\
\hline
\end{tabular}

\begin{tabular}{llll}
\hline Average $\Sigma F I C$ & $0.81 \pm 0.18$ & $0.68 \pm 0.46$ & $0.644 \pm 0.44$
\end{tabular}

non-interaction (1:9, drug:extract; $\Sigma F I C=1.7)$. No synergistic effect was seen with ether extracts, but 8 ratios resulted in additive effects $(0.6 \leq \Sigma F I C \leq 0.9)$ and 1 ratio a non-interactive effect (3:7, drug:extract; $\Sigma$ FIC $=1.2$ ). Strong correlations were observed between $\Sigma$ FIC values from erythromycin/acetone and erythromycin/chloroform combinations $(\rho=0.82)$, although no significant difference was found between the mean of their $\Sigma$ FIC values $(0.68 \pm 0.46$ and $0.644 \pm 0.44 ; p<0.05)$. The best $\Sigma$ FIC values were 0.2 for erythromycin/chloroform at 5:5, followed by 0.3 for all these combinations: erythromycin/acetone (at 7:3 and 3:7) and for erythromycin/chloroform (at 3:7 and 6:4). 


\section{DISCUSSION}

S. aureus is a pathogen long-recognized to be capable of developing drug resistance which increases patient treatment time, rate of morbidity and mortality, and associated financial costs (Pantosti, 2012). These factors make the search for new active agents against S. aureus highly relevant. In contrast to the well-known antimicrobial effects of I. suffruticosa (Leite et al., 2006; Carli et al., 2010), our present work is the first to evaluate organic solvent extracts for activity against clinical isolates of $S$. aureus strains (including two MRSA strains), as well their combinatory effects with a macrolide drug (erythromycin).

The organic extracts from I. suffruticosa leaves showed antimicrobial activity against all tested strains of $S$. aureus and, importantly, high inhibition zones were found against MRSA strains (UFPEDA 670 and UFPEDA 672). These two strains were isolated from different sources and exhibited multidrug-resistant profile (oxacillin-cefoxitin-erythromycin-clindamycin). The best anti$S$. aureus activity was shown by the acetone extract, since its $\mathrm{MIC}_{50}$ was 4-fold lower than the $\mathrm{MIC}_{50}$ values of the two other extracts. From chemical point of view, the acetone extract contains more flavonoids than ether and chloroform extracts. It is known that different species of genus Indigofera including I. suffruticosa are rich source of bioactive flavonoids (Hasan et al., 1993; Narender et al., 2006; Varanda et al., 2011; Perez et al., 2013). Previous chemical analysis from I. suffruticosa resulted in the identification of four quercetin derivatives. Although our result revealed that the antimicrobial properties might be associated with the presence of flavonoids, a characterization of acetone extract is necessary, even though this has not been our major focus.

We also showed that high temperature (up to $100^{\circ} \mathrm{C}$ ) had negligible effect on the anti-S. aureus activity of each extract, which may explain the effective traditional usage of $I$. suffruticosa in infusions prepared by prolonged boiling of its leaves (Corrêa, 1984). Similarly, the antimicrobial activities of our three organic extracts showed little change when submitted to $\mathrm{pH}$ values ranging from $\mathrm{pH} 3$ to $\mathrm{pH} 10$. Thermal and $\mathrm{pH}$ stabilities are noteworthy factors for development of new antimicrobial formulations by the cosmetic, food and pharmaceutical industries, and our findings encourage further research into use of our organic extracts.

Exploring combinatory effects of antimicrobial agents and natural products is an attractive strategy to overcome bacterial resistance (Betoni et al., 2006; Wink et al., 2012). Diverse targets are involved in the synergistic effects of drugs and plantderived products such as enzymes and substrates, metabolites, receptors, ion channels, transport proteins, DNA and RNA (Wagner, 2011; Yang et al., 2014). Our study establishes that all organic extracts from I. suffruticosa induce at least additive effects with erythromycin. In addition to its more potent antimicrobial activity, the synergestic effect of the acetone extract was higher than that of the chloroform extract, although this did not reach statistical significance and the $\Sigma$ FIC values of the two were strongly correlated. In contrast, the I. suffruticosa ether extract only showed additive effects or, in one tested ratio, a non-interactive effect. These results suggest these as a promising source of potential compounds to be used in combination of erythromycin (and other members of MLSB family).

I. suffruticosa extracts have been target of a various studies in order to prove their medicinal potential. Most of these works have shown that polar solvent extracts are more active (Table 1) as they are rich in phenolic compounds, flavonoids, carbohydrates, glycoproteins, indigo, alkaloids, and triterpenes (Leite et al., 2006; Carli et al., 2010; Lopes et al., 2011; Luiz-Ferreira et al., 2011; Almeida et al., 2013; Chen et al., 2013a,b). Furthermore, extracts from I. suffruticosa have been also shown key features to be used as a medicine such as lethal dose $50 \%(1600 \mathrm{mg} / \mathrm{kg}$ (ip) in mice (Almeida et al., 2013) and induction of phase II detoxification enzyme and increase of glutathione levels in rat Clone 9 liver cells (Chen et al., 2013b).

In summary this paper showed that organic extracts of I. suffruticosa are promising natural products for the development of new anti-S. aureus formulation given their antimicrobial inhibiting MRSA strains and their combination with erythromycin seems to be very perspective, thus deserving further studies in order to understand their mechanism of action.

\section{ACKNOWLEDGMENTS}

The authors are grateful to Conselho Nacional de Desenvolvimento Científico e Tecnológico (CNPq), Coordenação de Aperfeiçoamento de Pessoal de Nível Superior (CAPES) and Fundação de Amparo à Ciência do Estado de Pernambuco (FACEPE) for the financial support to this study. We express our gratitude to Prof. James Stuart Owen, from University College of London, for correcting the English language.

\section{REFERENCES}

Agra, M. F., Silva, K. N., Basílio, D. I. J. L., Freitas, P. F., and Barbosa-Filho, J. M. (2008). Survey of medicinal plants used in the region Northeast of Brazil. Rev. Bras. Farmacogn. 10, 472-508. doi: 10.1590/S0102-695X2008000300023

Almeida, E. R., Chaves, T. M., Luna, R. L. A., Silva, A. R., Aragão-Neto, A. C., Silva, L. L. S., et al. (2013). Anticonvulsant effect of Indigofera suffruticosa Mill: indication of involvement of the GABAergic system. Afr. J. Pharm. Pharmacol. 7, 622-628. doi: 10.5897/AJPP12.1262

Barros, G. M. C. C., and Teixeira, S. D. P. (2008). Pharmacobotanical studies of wild indigo species (Indigofera suffruticosa and Indigofera truxillensis, Leguminosae,) with pharmacological properties. Rev. Bras. Farmacogn. 18, 287-294. doi: 10.1590/S0102-695X2008000200024

Betoni, J. E. C., Mantovani, R. P., Barbosa, L. N., Di Stasi, L. C., and Fernandes, A. Jr. (2006). Synergism between plant extract and antimicrobial drugs used on Staphylococcus aureus diseases. Mem. Inst. Oswaldo Cruz 101, 387-390. doi: 10.1590/S0074-02762006000400007

Carli, C. B. A., Quilles, M. B., Maia, D. C., Lopes, F. C., Santos, R. Jr., FujimuraLeite, C. Q., et al. (2010). Antimycobacterial activity of Indigofera suffruticosa with activation potential of the innate immune system. Pharm. Biol. 48, 878-882. doi: 10.3109/13880200903303471

Chan, B. C., Han, X. Q., Lui, S. L., Wong, C. W., Wang, T. B., Cheung, D. W., et al. (2015). Combating against methicillin-resistant Staphylococcus aureustwo fatty acids from Purslane (Portulaca oleracea L.) exhibit synergistic effects with erythromycin. J. Pharm. Pharmacol. 67, 107-116. doi: 10.1111/jphp. 12315

Chan, B. C., Ip, M., Gong, H., Lui, S. L., See, R. H., Jolivalt, C., et al. (2013). Synergistic effects of diosmetin with erythromycin against ABC transporter over-expressed methicillin-resistant Staphylococcus aureus (MRSA) RN4220/pUL5054 and inhibition of MRSA pyruvate kinase. Phytomedicine 20, 611-614. doi: 10.1016/j.phymed.2013.02.007

Chen, C. C., Liu, C. S., Li, C. C., Tsai, C. W., Yao, H. T., Liu, T. C., et al. (2013b). Indigofera suffruticosa Mill extracts up-regulate the expression of 
the $\pi$ class of glutathione S-transferase and NAD (P) H: quinone oxidoreductase 1 in rat Clone 9 liver cells. Food Chem. Toxicol. 59, 610-617. doi: 10.1016/j.fct.2013.06.042

Chen, T. Y., Sun, H. L., Yao, H. T., Lii, C. K., Chen, H. W., Chen, P. Y., et al. (2013a). Suppressive effects of Indigofera suffruticosa Mill extracts on lipopolysaccharideinduced inflammatory responses in murine RAW 264.7 macrophages. Food Chem. Toxicol. 55, 257-264. doi: 10.1016/j.fct.2012.12.056

Chung, P. Y., Navaratnam, P., and Chung, L. Y. (2011). Synergistic antimicrobial activity between pentacyclic triterpernoids and antibiotics against Staphylococcus aureus strains. Ann. Clin. Microbiol. Antimicrob. 10, 1-6. doi: 10.1186/1476-0711-10-25

Clinical and Laboratory Standards Institute (2011). Performance Standards for Antimicrobial Susceptibility Testing; Twenty First Informational Supplement, M100S21. Wayne, PA.

Corrêa, M. P. (ed.). (1984). "Dicionário de plantas úteis do Brasil e das exóticas cultivadas," in Dicionário de Plantas úteis do Brasil e das Exóticas Cultivadas (Brasília: Imprensa Nacional), 1-172.

Coutinho, H. D. M., Costa, J. G. M., Lima, E. O., Falcão-Silva, V. S., and Junior, J. P. S. (2009). Herbal therapy associated with antibiotic therapy: potentiation of the antibiotic activity against methicillin- resistant Staphylococcus aureus by Turnera ulmifolia L. BMC Complem. Alter. Med. 9:13. doi: 10.1186/1472-6882-9-13

da Silva, L. C. N., Sandes, J. M., de Paiva, M. M., de Araújo, J. M., Figueiredo, R. C. B. Q. D., da Silva, M. V., et al. (2013). Anti-Staphylococcus aureus action of three Caatinga fruits evaluated by electron microscopy. Nat. Prod. Res. 27, 1492-1496. doi: 10.1080/14786419.2012.722090

de Oliveira, Y. L., Nascimento da Silva, L. C., da Silva, A. G., Macedo, A. J., de Araújo, J. M., Correia, M. T. S., et al. (2012). Antimicrobial activity and phytochemical screening of Buchenavia tetraphylla (Aubl.) R. A. Howard (Combretaceae: Combretoideae). Sci. World. J. 2012, 1-6, doi: $10.1100 / 2012 / 849302$

García Calixto, T., Rodríguez Gonzalez, M. E., Pinera Wiltshire, M. C., Martínez Monier, M. A., Santana Suárez, Y., and Hernández Contreras, N. (2011). Effective treatment of a patient infested with pediculus capitis by using $5 \%$ Indigofera suffruticosa Mill tincture. Rev. Cubana Med. Trop. 63, 275-277.

Hasan, A., Farman, M., and Ahmed, I. (1993). Flavonoid glycosides from Indigofera hebepetala. Phytochemistry 35, 275-276. doi: 10.1016/S0031-9422(00) 90552-1

Leite, S. P., Vieira, J. R. C., Medeiros, P. L., Leite, R. M. P., Lima, V. L. M., Xavier, H. S., et al. (2006). Antimicrobial activity of Indigofera suffruticosa. Evid. Based Complement. Alternat. Med. 3, 261-265. doi: 10.1093/ecam/ nel010

Lopes, F. C., Calvo, T. R., Colombo, L. L., Vilegas, W., and Carlos, I. Z. (2011). Immunostimulatory and cytotoxic activities of Indigofera suffruticosa (Fabaceae). Nat. Prod. Res. 25, 1796-1806. doi: 10.1080/14786419.2010.488624

Luiz-Ferreira, A., Cola, M., Barbastefano, V., Farias-Silva, E., Calvo, T. R., de Almeida, A. B., et al. (2011). Indigofera suffruticosa Mill as new source of healing agent: involvement of prostaglandin and mucus and heat shock proteins. J. Ethnopharmacol. 137, 192-198. doi: 10.1016/j.jep.2011.05.006

Narender, T., Khaliq, T., Puri, A., and Chander, R. (2006). Antidyslipidemic activity of furano-flavonoids isolated from Indigofera tinctoria. Bioorg. Med. Chem. Lett. 16, 3411-3414. doi: 10.1016/j.bmcl.2006.04.001

Palmer, A. C., and Kishony, R. (2013). Understanding, predicting and manipulating the genotypic evolution of antibiotic resistance. Nat. Rev. Genet. 14, 243-248. doi: $10.1038 / \mathrm{nrg} 3351$

Pankey, G. A., and Sabath, L. D. (2004). Clinical relevance of bacteriostatic versus bactericidal mechanisms of action in the treatment of Gram-positive bacterial infections. Clin. Infect. Dis. 38, 864-870. doi: 10.1086/381972

Pantosti, A. (2012). Methicillin-resistant Staphylococcus aureus associated with animals and its relevance to human health. Front. Microbiol. 3:127. doi: 10.3389/fmicb.2012.00127

Pereira, F. L., Fernandes, J. M., and Leite, J. P. V. (2012). Ethnopharmacological survey: a selection strategy to identify medicinal plants for a local phytotherapy program. Braz. J. Pharm. Sci. 48, 299-313. doi: 10.1590/S198482502012000200014
Perez, L. B., Li, J., Lantvit, D. D., Pan, L., Ninh, T. N., Chai, H. B., et al. (2013). Bioactive Constituents of Indigofera spicata. J. Nat. Prod. 76, 1498-1504. doi: $10.1021 / \mathrm{np} 400567 \mathrm{c}$

Salvador, I. S., Medeiros, R. M. T., Pessoa, C. R. M., Oliveira, D. M., Duarte, A. L. A., Fighera, R. A., et al. (2011). Experimental poisoning of guinea pig (Cavia porcellus) with Indigofera suffruticosa. Toxicon 57, 927-931. doi: 10.1016/j.toxicon.2011.03.007

Silva, M. I. G., Melo, C. T. V., Vasconcelos, L. F., Carvalho, A. M. R., and Souza, F. C. F. (2012). Bioactivity and potential therapeutic benefits of some medicinal plants from the Caatinga (semi-arid) vegetation of Northeast Brazil: a review of the literature. Rev. Bras. Farmacogn. 22, 193-207. doi: 10.1590/S0102695X2011005000171

Streit, J. M., and Jones, R. N., Sader, H. S. (2004). Daptomycin activity and spectrum: a worldwide sample of 6,737 Gram-positive organisms. J. Antimicrob. Chemother. 53, 669-674. doi: 10.1093/jac/dkh143

Tavares, L. S., Silva, C. S. F., Souza, V. C., Silva, V., Diniz, C. G., and Santos, M. O. (2013). Strategies and molecular tools to fight antimicrobial resistance: resistome, transcriptome, and antimicrobial peptides. Front. Microbiol. 4:412. doi: 10.3389/fmicb.2013.00412

Varanda, E. A., Calvo, T. R., Cardoso, C. R. P., Da Silva Moura, A. C., Dos Santos, L. C., Colus, I. M. S., et al. (2011). Mutagenic activity of Indigofera truxillensis and I. suffruticosa aerial parts. Evid. Based Complement. Alternat. Med. 2011, 1-9. doi:10.1093/ecam/nep123

Vuuren, S., and Viljoen, A. (2011). Plant-based antimicrobial studies-methods and approaches to study the interaction between natural products. Planta Med. 77, 1168-1182. doi: 10.1055/s-0030-1250736

Wagner, H. (2011). Synergy research: approaching a new generation of phytopharmaceuticals. Fitoterapia 82, 34-37. doi: 10.1016/j.fitote.2010.11.016

Wagner, H., and Bladt, S. (2009). Plant drug analysis-A thin layer chromatography atlas. Berlin: Springer Verlag.

Wagner, H., and Ulrich-Merzenich, G. (2009). Synergy research: approaching a new generation of phytopharmaceuticals. Phytomedicine 16, 97-110. doi: 10.1016/j.phymed.2008.12.018

Wink, M., Ashour, M. L., and El-Readi, M. Z. (2012). Secondary metabolites from plants inhibiting $\mathrm{ABC}$ transporters and reversing resistance of cancer cells and microbes to cytotoxic and antimicrobial agents. Front. Microbiol. 3:130. doi: $10.3389 /$ fmicb.2012.00130

Yang, Y., Zhang, Z., Li, S., Ye, X., Li, X., and He, K. (2014). Synergy effects of herb extracts: pharmacokinetics and pharmacodynamic basis. Fitoterapia 92, 133-147. doi: 10.1016/j.fitote.2013.10.010

Zakavi, F., Golpasand Hagh, L., Daraeighadikolaei, A., Farajzadeh Sheikh, A., Daraeighadikolaei, A., and Leilavi Shooshtari, Z. (2013). Antibacterial effect of juglans regia bark against oral pathologic bacteria. Int. J. Dent. 2013, 1-5. doi: $10.1155 / 2013 / 854765$

Conflict of Interest Statement: The authors declare that the research was conducted in the absence of any commercial or financial relationships that could be construed as a potential conflict of interest.

Received: 31 July 2014; accepted: 06 January 2015; published online: 02 February 2015. Citation: Bezerra dos Santos AT, Araújo TFS, Nascimento da Silva LC, Silva CB, Oliveira AFM, Araújo JM, Correia MTS, Lima VLM (2015) Organic extracts from Indigofera suffruticosa leaves have antimicrobial and synergic actions with erythromycin against Staphylococcus aureus. Front. Microbiol. 6:13. doi: 10.3389/fmicb. 2015.00013

This article was submitted to Antimicrobials, Resistance and Chemotherapy, a section of the journal Frontiers in Microbiology.

Copyright (c) 2015 Bezerra dos Santos, Araújo, Nascimento da Silva, Silva, Oliveira, Araújo, Correia, Lima. This is an open-access article distributed under the terms of the Creative Commons Attribution License (CC BY). The use, distribution or reproduction in other forums is permitted, provided the original author(s) or licensor are credited and that the original publication in this journal is cited, in accordance with accepted academic practice. No use, distribution or reproduction is permitted which does not comply with these terms. 